\title{
Incidence of Viruses and Viruslike Diseases of Sweetpotato in Uganda
}

Settumba B. Mukasa, Department of Crop Science, Faculty of Agriculture, Makerere University, P.O. Box 7062, Kampala, Uganda, and Department of Plant Biology, Genetics Centre, Swedish University of Agricultural Sciences (SLU), Box 7080, SE-750 07 Uppsala, Sweden; Patrick R. Rubaihayo, Department of Crop Science, Faculty of Agriculture, Makerere University, P.O. Box 7062, Kampala, Uganda; and Jari P. T. Valkonen, Department of Plant Biology, Genetics Centre, Swedish University of Agricultural Sciences (SLU), Box 7080, SE-750 07 Uppsala, Sweden, and Department of Applied Biology, University of Helsinki, Finland

\begin{abstract}
Mukasa, S. B., Rubaihayo, P. R., and Valkonen, J. P. T. 2003. Incidence of viruses and viruslike diseases of sweetpotato in Uganda. Plant Dis. 87:329-335.

Sweetpotato plants were surveyed for viruslike diseases and viruses in the four major agroecological zones of Uganda. Testing of 1,260 sweetpotato plants, of which 634 had viruslike symptoms, showed that virus disease incidence ranged from $2.7 \%$ (Soroti district, short grassland-savannah zone) to $20 \%$ (Mukono district, tall grass-forest mosaic zone). Sweet potato chlorotic stunt virus (SPCSV), Sweet potato feathery mottle virus (SPFMV), Sweet potato mild mottle virus (SPMMV), and sweet potato chlorotic fleck virus (SPCFV) were serologically detected and positive results confirmed by immunocapture reverse transcriptase polymerase chain reaction (IC-RT-PCR) and subsequent sequence analyses of the amplified fragments, except SPCFV, which lacked sequence information. SPCSV and SPFMV were detected in all the 14 districts surveyed, whereas SPMMV and SPCFV were detected in 13 and 8 districts, respectively. Logistic regression analysis revealed that SPCSV and SPFMV, SPFMV and SPMMV, and SPFMV and SPCFV more frequently occurred together than any other virus combinations or as single virus infections. Co-infections of SPCSV with SPFMV and/or SPMMV were associated with more severe and persistent symptoms than infections with each of the viruses alone. Several plants (11\%) displaying viruslike symptoms did not react with the virus antisera used, suggesting that more viruses or viruslike agents are infecting sweetpotatoes in Uganda.
\end{abstract}

Additional keywords: aphid, Bemisia tabaci, erinose, hairiness, Ipomoea batatas, Ipomoea setosa, mite, whitefly

Sweetpotato, Ipomoea batatas (L.) Lam., is the third most important root crop in the world after potato (Solanum tuberosum L.) and cassava (Manihot esculenta Crantz) (12). Although sweetpotato is grown in many African countries, the crop is most important in East Africa (7). In Uganda, sweetpotato is the second most important root crop after cassava and is grown in virtually all districts of the country. It plays a significant role in the farming and food systems (5). As a starch staple, it ranks second to banana in central and western Uganda and second to cassava in the eastern region. Sweetpotato provides household food security because it stores well in the soil as a famine reserve crop and performs well in marginal soils. Thus, the low level of agricultural inputs requirement, high productivity per unit area (42), good nutritional value, and increasing

Corresponding author: Jari Valkonen

E-mail: jari.valkonen@ vbiol.slu.se

Accepted for publication 7 November 2003.

Publication no. D-2003-0212-02R

(C) 2003 The American Phytopathological Society demand for food make sweetpotato an ideal starch staple crop for food security in subsistence economies. However, production is greatly constrained, particularly by viral diseases that cause yield reductions of 56 to $98 \%(17,31)$.

The first report of a suspected virus disease of sweetpotato in Eastern Africa was in 1939 from Ituri province of the Democratic Republic of Congo and then in 1944 from Uganda (18). Later, viral diseases in sweetpotato were reported in Kenya, Tanzania, Rwanda, Burundi, Malawi, and Transvaal Province of South Africa (37). Early plant-infectivity studies in East Africa indicated the occurrence of two viruses (virus $\mathrm{A}$ and virus $\mathrm{B}$ ) that were aphid- and whitefly-transmitted, respectively (37). The description of virus $\mathrm{A}$ is very similar to Sweet potato feathery mottle virus (SPFMV, genus Potyvirus, family Potyviridae), while that of virus B closely resembles Sweet potato mild mottle virus (SPMMV, genus Ipomovirus, family Potyiridae), which has not been reported outside the East African region $(9,19)$. Since then, many viral diseases of sweetpotato have been described from several parts of the world $(8,30)$. Worldwide, up to 19 different viruses have been described in sweetpotato, but only 11 of them are currently recognized by the International Committee of Taxonomy for Viruses (39). With the emerging sequence data for viruses and virus isolates from different parts of the world, it will be possible to more clearly distinguish the different viruses that infect sweetpotato.

With changes in the cropping systems, vector population dynamics (41), and cultivar introductions, sweetpotato viruses have become very important in Uganda, particularly in the Lake Victoria basin (22). Sweet potato virus disease (SPVD), caused by the co-infection of Sweet potato chlorotic stunt virus (SPCSV, genus Crinivirus, family Closteroviridae) and SPFMV (16), is the most important disease of sweetpotato in Uganda (17). Previous studies in Uganda concentrated on serodiagnosis of the SPVD, plant response to the disease $(3,17,23)$, and molecular studies on the two casual viruses $(1,25,26)$. Other studies have reported the incidence of SPVD $(5,17)$ with less emphasis on a countrywide distribution and potential associations of co-occurrence of the known sweetpotato viruses.

Serological detection of SPFMV, SPMMV, SPCSV, Sweet potato latent virus (SPLV, genus Potyvirus), Sweet potato mild speckling virus (SPMSV, genus Potyvirus), sweet potato chlorotic fleck virus (SPCFV), sweet potato caulimo-like virus (SPCaLV), and C-6 virus $(4,17)$ is possible with antisera available from the International Potato Center (CIP), Lima, Peru. However, this study mainly focused on SPFMV, SPCSV, SPCFV, and SPMMV, for which the serological and/or molecular diagnostic methods available are more specific, reliable, and sensitive than those for the remaining viruses. The aim of the study was to provide a quantitative assessment of the incidence of these viruses and virus-diseased plants, and associations of co-occurrence between different viruses following a sampling procedure that took into account the four major agroecological zones of Uganda.

\section{MATERIALS AND METHODS}

Sampling and plant materials. A multistage sampling procedure (29) was followed where Uganda was stratified into the four major agroecological zones repre- 
sented by 14 major sweetpotato growing districts (Fig. 1). From each district, one subcounty was selected, and sweetpotato farmers in the subcounty were used as the sampling frame. The number of plants with apparent symptoms of viruses (6) and/or symptoms typical of sweetpotato viruses $(8,16)$ and the total number of plants assessed were recorded for each selected farmer's sweetpotato field. The observational unit was a sweetpotato plant, taking into account the trailing nature of the crop, in the selected sweetpotato field. A form of cluster sampling that takes into account the binary nature of diseased plants (21) was done. To minimize bias in estimation of actual disease incidence in a field, a systematic $X$ sampling pattern (33) was followed and the disease status recorded for 25 plants along each of the four arms. Thus, 100 plants were recorded in each field. Field disease incidence, percentage of visually diseased plants over the total number of plants assessed (27), was calculated as the average score of 10 sweetpotato fields per district where one-percent unit represents one diseased plant out of 100 .

From each of the 10 sweetpotato fields per district, five diseased and five symp- tomless sweetpotato plants were systematically sampled. The top 20 to $30 \mathrm{~cm}$ of the apical sweetpotato vine was used to establish a disease nursery in an insect-proof screenhouse at Makerere University Agricultural Research Institute, Kabanyolo. This allowed observation of symptoms for all the sampled vines in a similar environment and for subsequent virus disease diagnostic studies. A description of symptoms on each sampled sweetpotato vine was done both in the field and later in screenhouse. Information was collected from sweetpotato fields on agronomy, cultivars grown, and the incidence of plants with virus or viruslike symptoms.

Sero-prevalence of viruses. Nitrocellulose membrane enzyme-linked immunosorbent assay (NCM-ELISA) (15) was used for routine serological testing of plant samples and was carried out using the kit provided by CIP. The kit contained polyclonal antibodies to eight viruses (SPFMV, SPCSV, SPMMV, SPCFV, SPLV, SPMSV, SPCaLV, and C-6) and NCM strips spotted with sap from virus-positive and noninfected control plants. However, detection of SPLV, SPMSV, SPCaLV, and C-6 was not continued since reactions to virus-

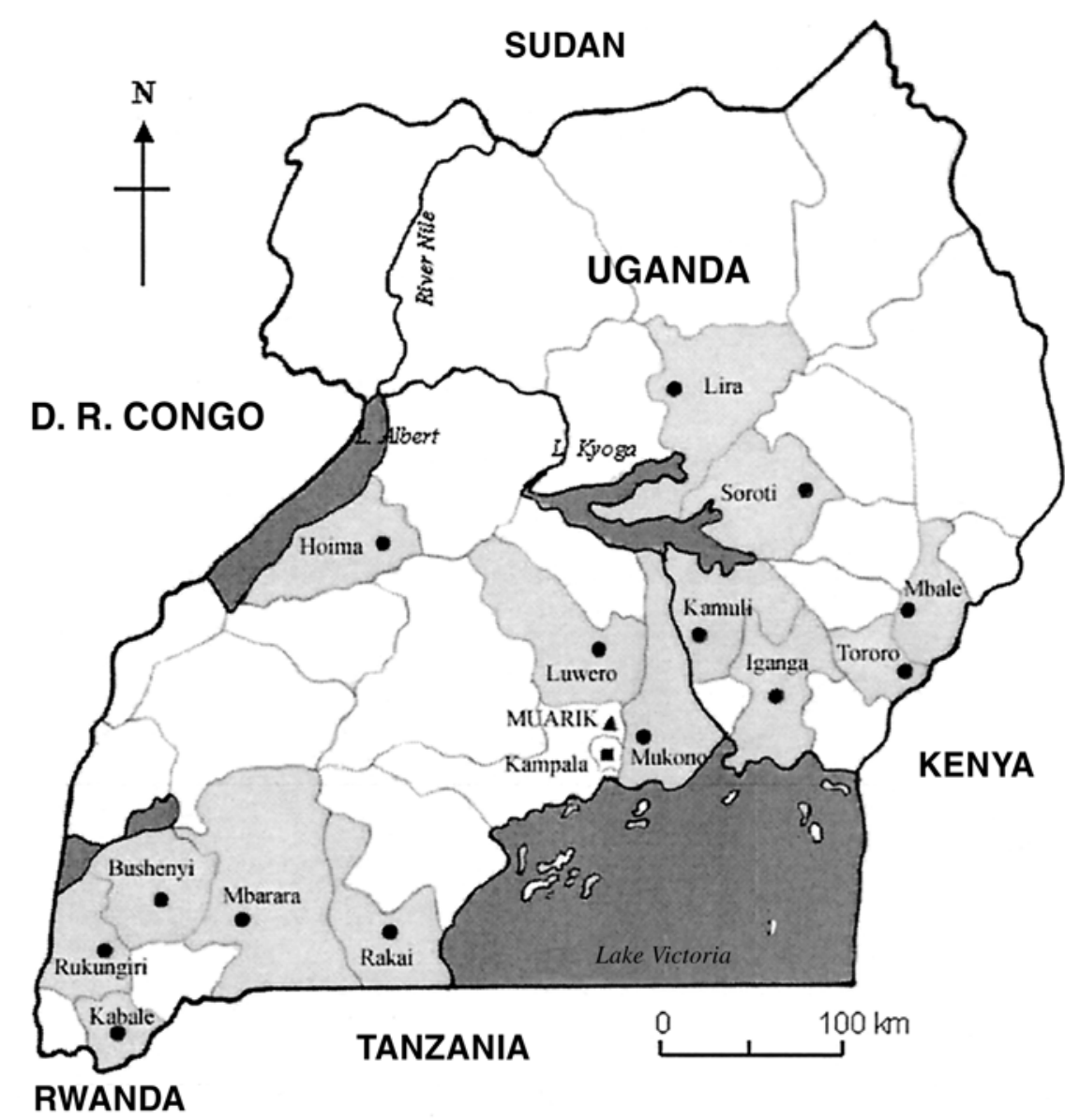

Fig. 1. Map of Uganda showing the surveyed districts representing the four agroecological zones. Mukono, Luwero, Kamuli, and Iganga are located in the tall grass-forest mosaic zone (I); Kabale and Rukungiri districts are in the high altitude or Montane zone (II); Bushenyi, Mbarara, Rakai, Hoima, Mbale, and Tororo are in the southern and western tall grassland zone (III); Lira and Soroti are in the northern and eastern short grassland zone (IV). positive controls were weak and some cross-reactivity with noninfected control samples was observed. A leaf disk $(1 \mathrm{~cm}$ diameter) was taken from a top, middle, and lower leaf (preferably with symptoms) of each plant and tested for each of the eight viruses. Each sample was scored as a binary variable (virus-positive $=1$; virusnegative $=0$ ).

Graft-inoculation. Scions from selected sweetpotato plants that tested serologically positive for single viruses were grafted to Ipomoea setosa Kerr., a sensitive indicator plant for sweetpotato viruses (35). Graft inoculation experiments were carried out for SPFMV, SPMMV, SPLV, SPCFV, and SPCSV. Similarly, scions from vines that were negative in NCM-ELISA but had viruslike symptoms were graft-inoculated to I. setosa. In I. setosa, high virus titers can be obtained and symptoms due to different viruses and virus complexes compared directly since this avoids symptom differences due to genetic differences of sweetpotato cultivars. The grafted I. setosa plants were (i) observed for symptoms, (ii) tested for viruses using NCM-ELISA, and (iii) tested for SPFMV, SPCSV, and SPMMV by IC-RT-PCR (see below).

Virus detection by IC-RT-PCR. Virus detection by immunocapture reverse transcriptase polymerase chain reaction (ICRT-PCR) was carried out on leaf samples as described (32). The following virusspecific primers were used: $\mathrm{CP} 1$ and $\mathrm{CP} 2$ for SPCSV (1), CP106 and UTR34 for SPFMV (25), and MMA1 (9) and a poly(T) primer for SPMMV. First strand synthesis of viral cDNA was carried out with the reverse primer using Moloney murine leukemia virus reverse transcriptase (M-MLV-RT) (Promega, Madison, WI) as described (32). PCR amplification of the viral sequence was carried out using the respective forward and reverse primers and the viral cDNA as a template. The PCR mix contained $1 \times$ PCR buffer, $2 \mathrm{mM}$ $\mathrm{MgCl}_{2}, 0.2 \mathrm{mM}$ dNTPs, $0.6 \mu \mathrm{M}$ forward and reverse primers, $5 \mu \mathrm{l}$ of sample cDNA, 2.5 U Taq polymerase (MBI Fermentas), and sterile, distilled, and deionized water to a final volume of $50 \mu \mathrm{l}$. The cDNA was first denatured at $94^{\circ} \mathrm{C}$ for $2 \mathrm{~min}$ and then amplified through 34 thermal cycles of $94^{\circ} \mathrm{C}$ for $30 \mathrm{~s}, 50^{\circ} \mathrm{C}$ for $30 \mathrm{~s}, 72^{\circ} \mathrm{C}$ for 1 min, and ended by a final extension step at $72^{\circ} \mathrm{C}$ for $10 \mathrm{~min}$. The PCR products were separated by electrophoresis on a $1 \%$ agarose gel that contained ethidium bromide and visualized under UV light.

Total nucleic acid extraction and broad-spectrum detection of viruses. Total RNA was isolated using the hotphenol method (40), or the TRIzol LS Reagent (InVitrogen Ltd., Groningen, Netherlands) according to the manufacturer's instructions, from sweetpotato or $I$. setosa putatively infected with SPLV and SPCFV for which no amplification was realized from IC-RT-PCR. Similarly, total 
RNA was extracted from plants with diseases with an unidentified etiology (DUEs). The total RNA was used for RTPCR amplification with potyvirus-specific degenerate primers (14) since SPLV (10) and SPCFV (13) are thought to be potyviruses. Total DNA was extracted from sweetpotato plants with viruslike symptoms using a method described (34) and used for a broad spectrum PCR detection of Geminiviruses as described (43).

Statistical analysis. The frequencies of occurrence of each virus or viruses in the same plant were used to investigate potential associations between the occurrences of two or more viruses in the same host plant. Use of logistic regression allows prediction or determination of association between a qualitative variable (presence or absence of a virus; 1 or 0 ) from observations of one or more other variables (viruses), by fitting a logistic function to the data using the maximum likelihood approach (20). Binary logistic regression analysis was done on the frequencies of occurrence of different viruses in the diseased plants using MINITAB statistical software (State College, PA). Each virus was used as a response variable to determine the maximum likelihood of cooccurrence with the rest of the viruses. The odds ratio, an estimate of the change in the odds for an outcome (virus 1) if the state of the second virus changes by 1 , was determined for each virus combination.

\section{RESULTS}

Virus disease incidence. Farmers often associated virus and viruslike symptoms with other factors than viruses, e.g., sun scorching, low soil fertility, or soilborne insect pests, but acknowledged the need for clean planting material for improved productivity. Most farmers grew more than three sweetpotato cultivars in the same garden. Over 200 cultivar names, many probably synonymous, were recorded in the surveyed areas. Some cultivars, notably Bitambi, Dimbuka, Kawogo, Kisakyamaria, Muvasoroti, Sukaali, and Tanzania, were extensively grown in the surveyed districts. These cultivars were reported by farmers to yield well in different types of soil and/or to be resistant to pathogens.

Diseases apparently caused by viruses were common in the areas surveyed. The highest average virus disease incidences of $20 \%$ were observed in Mukono district (Fig. 2), which lies in the tall grass-forest mosaic zone (Fig. 1). Lowest disease incidence levels of $2.7 \%$ were recorded in Soroti district (Fig. 2), which lies in the short grassland zone (Fig. 1). Incidences varied greatly from field to field within a district, giving rise to large standard errors (Fig. 2). Consequently, disease incidence at a district level was not significantly different except for Lira and Soroti. For some districts that had high virus disease incidences, it was possible to find sweetpotato fields that were devoid of symptomatic plants. However, a trend in disease incidence could be observed at the level of agroecological zone, lower disease incidences prevailing in the short grassland savannah zone of Soroti and Lira (Fig. 2). The "hairy disorder" was sporadic in western and eastern districts, while the "leafclearing syndrome" was more widespread in eastern districts of Soroti, Tororo, and Kamuli. In Soroti district, the leaf-clearing syndrome was more prevalent than the symptoms associated with known viruses in four of the 10 fields surveyed.

Incidence of sweetpotato viruses. A total of 1,260 sweetpotato plants from 140 farmers' fields were successfully established in the screenhouse and tested for viruses. A total of 634 plants had viruslike disease symptoms. In these plants, SPCSV $(67.5 \%)$, followed by SPFMV $(63.8 \%)$, recorded very high incidences. SPCSV and SPFMV were detected in all the surveyed sweetpotato fields. SPMMV seemed to be the third most prevalent virus. It was detected in $24.6 \%$ of the diseased plants and in 13 out of the 14 districts (Fig. 3). Incidence of SPMMV was especially high in Mukono and Rukungiri districts. SPCFV was detected in $5.2 \%$ of the diseased plants and was the least frequent of the four reliably detected viruses. It was prevalent in eight out of 14 districts, especially in the districts of Hoima and Lira (Fig. 3). Virus incidence per cultivar could not be determined due to many and sometimes synonymous cultivar names. As many as 70

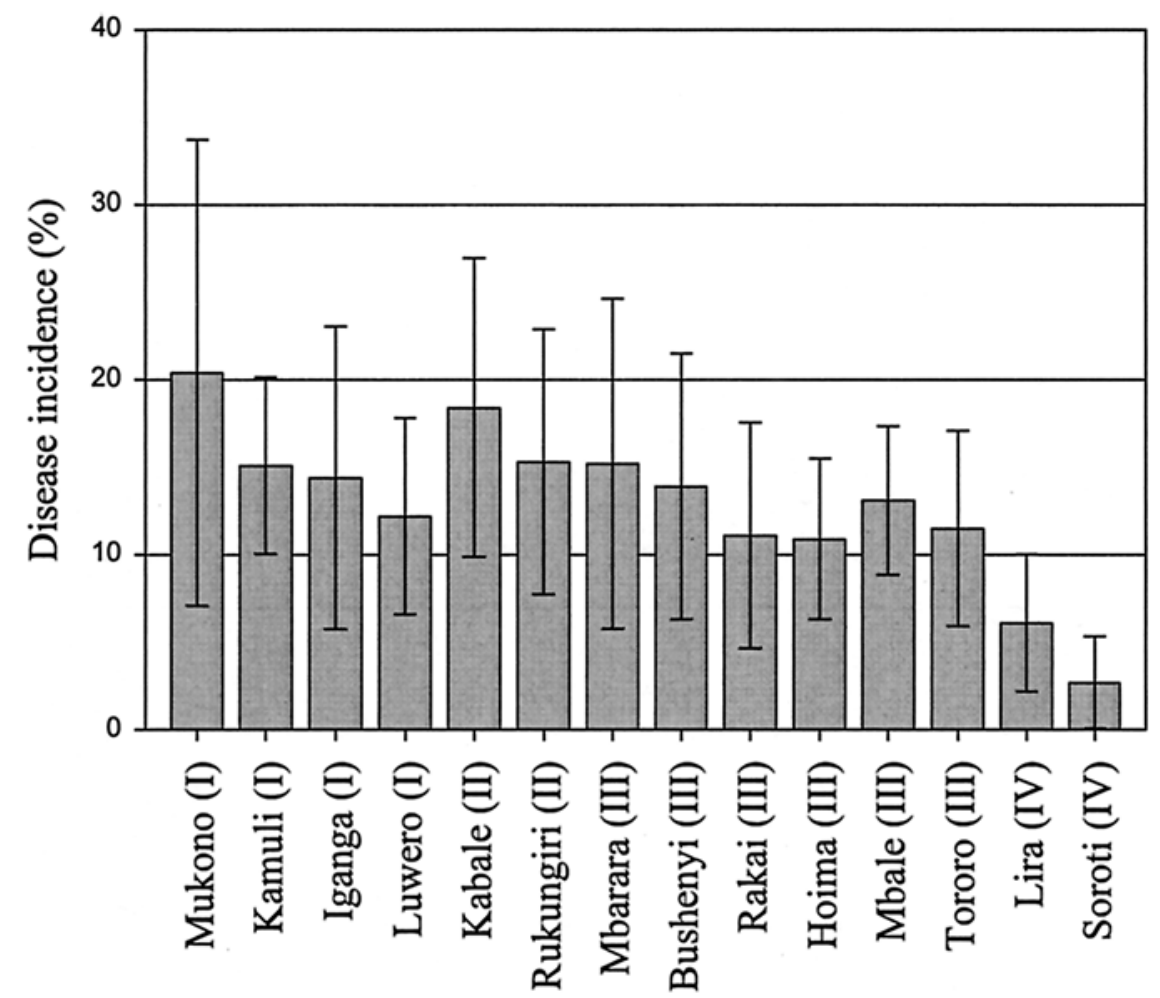

Fig. 2. Incidence of sweetpotato plants with viruslike symptoms in sweetpotato-growing districts of Uganda representing the four major agroecological zones (I to IV). Incidences in Soroti and Lira are significantly lower $(P<0.05)$ than in the other districts. plants $(11.1 \%)$ of the apparently diseased plants did not react with any antisera used (Fig. 4). The symptoms resembled those caused by viruses (6). Hence, these Diseased plants with Unidentified Etiology (DUE) could be infected with viruses that in this study and/or viruses that have not yet been described in sweetpotato.

Besides using virus-specific antisera in ELISA, SPCSV was detected in a few plants by IC-RT-PCR using the SPCSVspecific primers $\mathrm{CP} 1$ and $\mathrm{CP} 2$, which amplify a 1.15-kb fragment of the SPCSV genome (1). Also, several plants that tested positive for SPMMV and SPFMV in NCM-ELISA were tested using IC-RTPCR with potyvirus-specific degenerate primers (14), resulting in the expected 1.8$\mathrm{kb}$ product. Negative control samples (virus-free leaves) gave no products. Virus identification was further confirmed by cloning and partial sequencing of the PCR products and comparison to the sequences available in databanks (data not shown). SPFMV and SPMMV were distinguished using virus-specific primers designed based on sequences of the 3 '-terminal genomic region of the respective virus $(9,25)$. However, the potyvirus-specific degenerate primers did not amplify any PCR products from plants that were positive for SPCFV in ELISA, which is not consistent with the previous suggestion that SPCFV may be a potyvirus (13). No amplification products were obtained using the primers designed for detection of geminiviruses. have been described but were not tested for 
Multiple virus infections. Thirty-five percent of the diseased plants tested positive for only one of the four viruses studied, whereas $54 \%$ were naturally infected with two or more viruses (Fig. 4). The most common of the multiple infections was double infection with SPFMV and SPCSV (32.4\%), followed by the triple infection of SPFMV, SPMMV, and SPCSV (12.6\%). SPCSV was the most frequently detected virus, both in single and mixed infections (Fig. 4), and it was associated with severe and persistent symptoms. The odds for detecting double infections of SPCSV and SPFMV were significant (odds ratio $=2.89, P=0.000$; Table 1 ). Similarly, for plants infected with SPFMV there were significant odds (odds ratio $=$ 2.22, $P=0.066$; Table 1) for detecting double infections with SPCFV. Furthermore, the odds for co-occurrence of SPFMV and SPMMV were significant (odds ratio $=1.74, P=0.066$; Table 1 ). However, SPCSV did not exhibit significant co-occurrence with SPMMV (Table 1 ), yet both viruses are reported to be transmitted by whiteflies (Bemisia tabaci) $(19,41)$.

Types of viruslike diseases. The viruslike symptoms observed in plants in the field were more pronounced in new shoots grown from cuttings in the screenhouse. Some of the observed symptoms on different cultivars included chlorotic spots, mottling, general chlorosis, leaf clearing, leaf distortion/ruffle, leaf curling, mosaic, purpling, stunting, thinning, vein banding, and vein chlorosis (Fig. 5). Most sweetpotato plants that tested positive for only SPFMV intermittently developed mottle symptoms (Fig. 5B). The type of mottling in most plants that tested positive for only SPMMV could be distinguished from the mottling in plants infected with SPFMV (compare Fig. 5C to 5B). SPMMV also

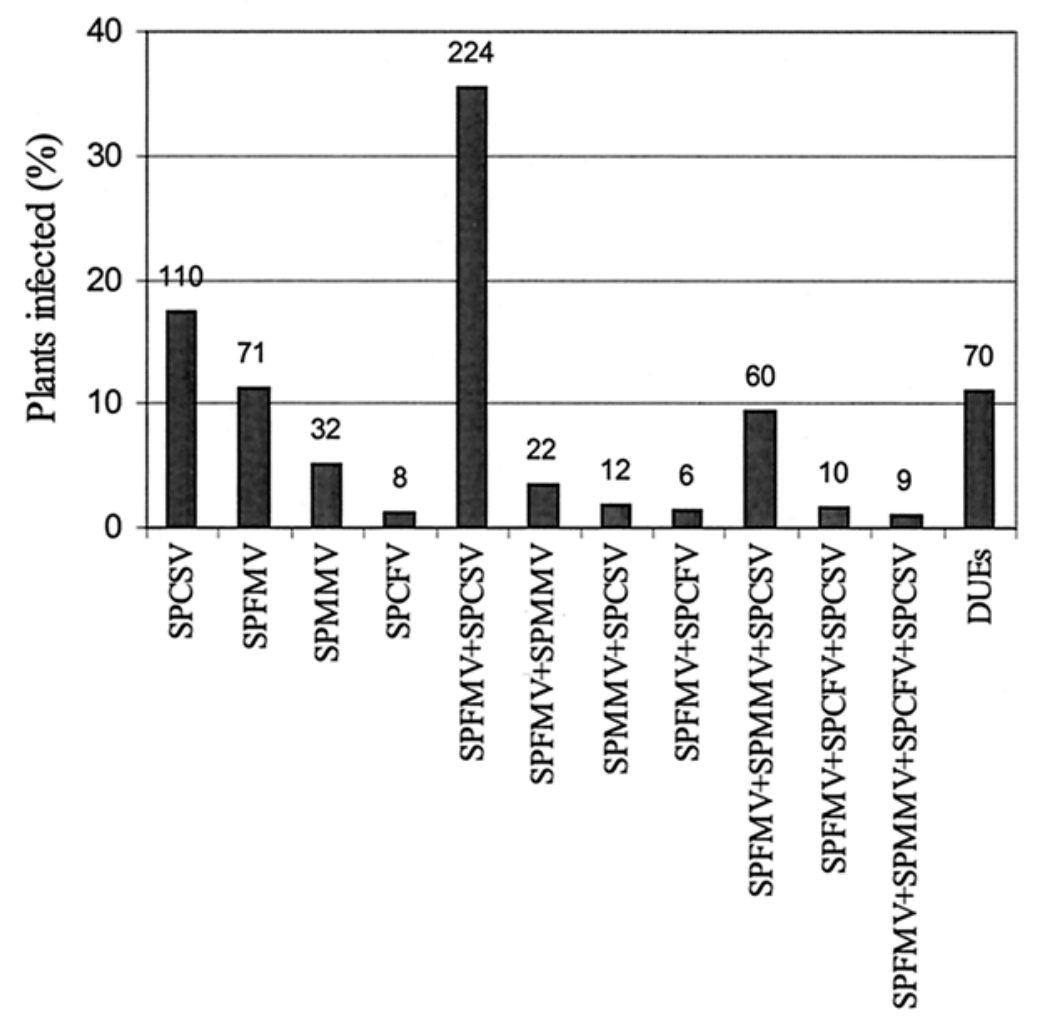

Fig. 4. Natural occurrence of single and mixed virus infections in symptomatic sweetpotato plants. Number of plants detected with a virus or viruses is indicated above each bar. ar

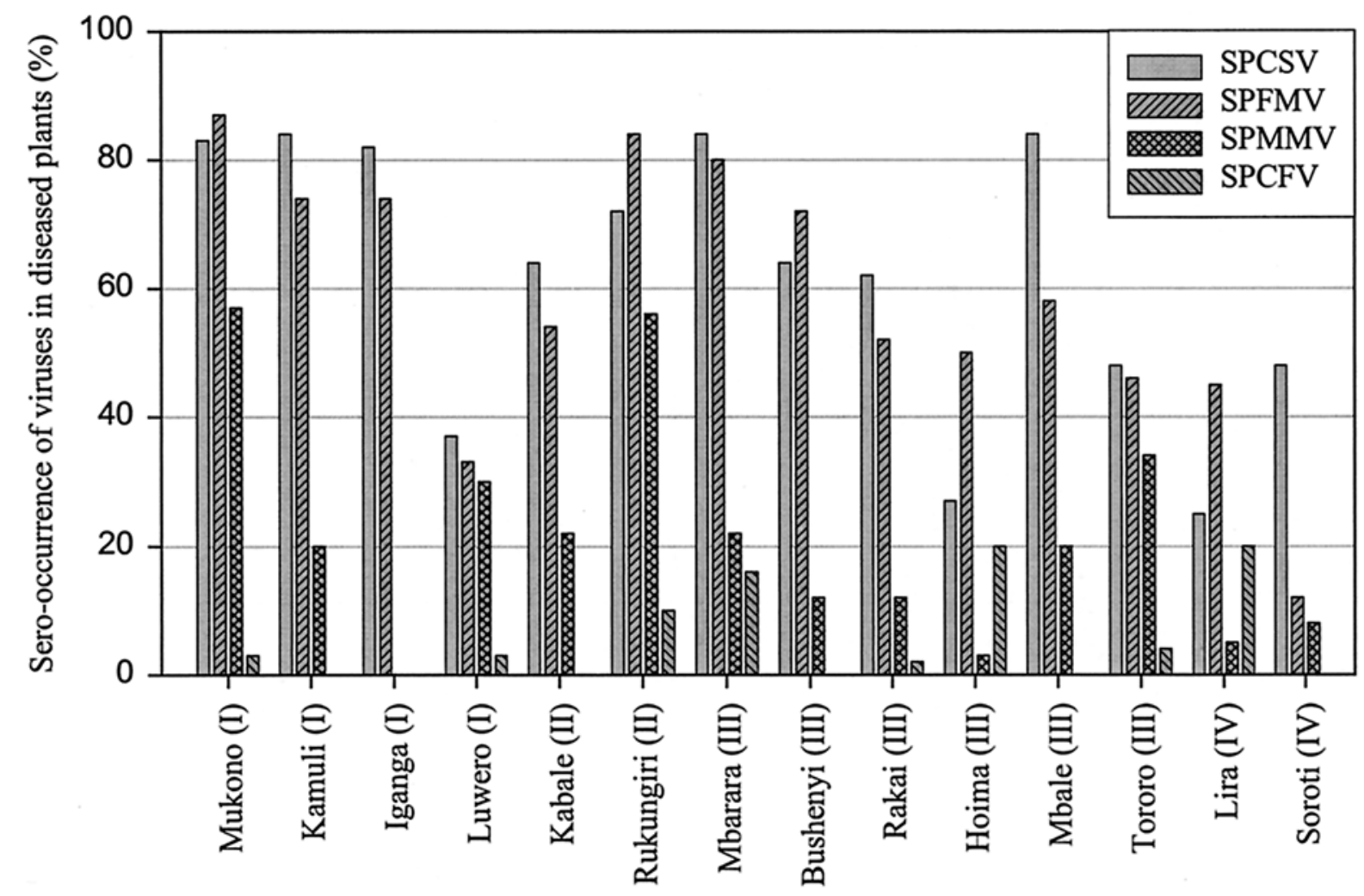

Fig. 3. Incidence of sweetpotato viruses in diseased plants sampled from sweetpotato-growing districts of Uganda representing the four major agroecological zones (I to IV). 
induced mild vein chlorosis and sometimes reduced growth. In I. setosa, SPFMV induced mottling and vein clearing (Fig. 5N), whereas SPMMV induced distinct yellow vein chlorosis (Fig. 5O). Symptoms associated with SPCSV included stunting of the sweetpotato plant, curling of the leaf tips in some cultivars, general mild chlorosis that gave a pale appearance (Fig. 5D), and purpling of the lower leaves (Fig. 5E). Plants that were positive for SPCFV were generally pale with occasional leaf crinkling or mottling (Fig. 5I). Symptoms, particularly for single infections of SPFMV and SPMMV, in different cultivars and I. setosa were most prominent 3 to 5 weeks after replanting or graft inoculation, after which they receded. However, symptoms associated with SPCFV and SPCSV could not easily be distinguished in $I$. setosa; both viruses were associated with faint chlorotic spots, pale leaves, and stunting. Multiple infections, especially those involving SPCSV, were associated with severe and persistent symptoms (Fig. 4G and $\mathrm{H}$ ). A hairiness disorder (Fig. 5L) was observed on several cultivars (and sometimes on neighboring weeds of the family Labiaceae) and was highly associated with fibrous root development. Some plants that were hairy were also positive for SPMMV only, and upon repeated propagation the hairiness could fade away but vein chlorosis could still be observed (Fig. 5F). In a previous study, the hairiness disorder was associated with feeding by Eriophyid mites (36).

A severe DUE characterized by chlorotic leaves containing "dark green islands" (DGI) $(28,38)$ was also observed on sweetpotato plants (Fig. 5J). When scions of these plants were graft-inoculated to different sweetpotato cultivars, a range of symptoms was observed, including clearing of leaf margins (Fig. 5K) or main veins, minor to severe leaf curling and leaf graying, and development of DGI. This DUE (leaf-clearing syndrome) was monitored for 1 year in plants periodically cut down and regrown in a screenhouse and a glasshouse in Uganda and Sweden, respectively, and the symptoms were found to persist. The affected plants tested negative with all virus antisera used.

The vigorous and healthy looking plants sampled from the fields during the survey did not develop symptoms in the screenhouse and did not react with any virus antisera.

\section{DISCUSSION}

The use of cluster sampling (21) provided a means of comparing variation in incidence and distribution of sweetpotato viruses. SPCSV and SPFMV were detected in all the surveyed sweetpotato fields, suggesting their occurrence in Uganda wherever sweetpotatoes are grown. SPCSV was detected most frequently, both in single and mixed infections. It caused persistent symptoms and was associated with very severe symptoms in mixed infection with other viruses. These observations propose SPCSV as the most important virus that infects sweetpotato in Uganda. SPFMV was also very common. Earlier reports have indicated that SPFMV is the most prevalent sweetpotato virus in Uganda (17) and to be found nearly everywhere sweetpotatoes are grown in the world (8). Many strains of SPFMV have been identified $(23,25)$, and it has been referred to by many names in different parts of the world (8).

Our data suggest that SPMMV is the third most prevalent virus in Uganda and was more frequently detected than earlier reported (17). SPCFV, previously suggested to be a potyvirus (13), was the least frequent of the four viruses studied. In the plants reacting clearly positive for SPCFV in ELISA, the virus was not detected with IC-RT-PCR and RT-PCR with the potyvirus-specific degenerate primers, which makes us suspect that SPCFV may not be a potyvirus. Sequence information is required for its precise classification.

Almost $90 \%$ of the 634 symptomatic plants tested positive with at least one of the four virus-specific antisera used, which suggests that the four viruses studied are largely responsible for the virus diseases of sweetpotato in Uganda. However, it was noted that the high incidence of SPCSV and SPFMV impose a difficulty in observing novel types of symptoms and partially limited the possibilities of detecting putative new viruses. Some plants did not react with any available virus antisera, yet they displayed viruslike symptoms. Therefore, more viruses or viruslike agents than the four viruses tested in this study seem to infect sweetpotatoes in Uganda, the leafclearing syndrome being the most significant DUE.

SPCSV (41) and SPMMV (19) are reported to be transmitted by whiteflies, which are more abundant in sweetpotato fields than the aphids that transmit SPFMV and SPCFV but do not colonize sweetpotato $(4,13)$. It was hypothesized that the viruses with a common vector species could exhibit a high frequency of cooccurrence. However, this was supported by our data only concerning the aphidtransmitted SPFMV and SPCFV. In con- trast, the incidence data (Fig. 4) and the cooccurrence analysis (Table 1) suggested lack of association between the whiteflytransmitted SPCSV and SPMMV in sweetpotato plants in the field. Our data may suggest that SPCSV and SPMMV are transmitted by different biotypes of $B$. tabaci, or may reflect differences in transmission efficiency of SPCSV and SPMMV by whiteflies, which requires further study. Unexpectedly, there was a significant association with the aphid- and whiteflytransmitted viruses (SPFMV and SPCSV, and SPFMV and SPMMV) (Table 1). The explanation for the observed common cooccurrence of SPFMV and SPCSV may at least partially be that infection with SPCSV suppresses the natural resistance to SPFMV in sweetpotato cultivars, which results in elevated titers of SPFMV and makes it more readily detectable (24). On the other hand, SPCSV seems to synergize also with SPMMV (our unpublished data), which, however, was not reflected as a commonly found co-occurrence of SPCSV and SPMMV in sweetpotato plants in the field. Whether SPFMV and SPMMV express synergism in co-infected plants has not been studied.

Most Ugandan farmers use the apical 25 to $30 \mathrm{~cm}$ of the vines from their previous crop (or obtain them free from their neighbors) as the planting material. Despite the lack of a virus eradication system for production of indexed sweetpotato planting materials, our results (average disease incidence $<20 \%$ ) indicate that Ugandan farmers are successful in obtaining a reasonable proportion of virus free plants by selecting for healthy and vigorous vines for the next cropping cycle or season. This was in agreement with the previous observations of apparent absence of viruses in most symptomless fieldgrown sweetpotato in Uganda (17). Similar to our results, the previous studies also report severe symptoms to be associated with co-infections with multiple viruses $(2,11,16)$.

The short grassland zone of Soroti and Lira districts exhibited low virus disease incidences. This agroecological zone mostly supports annual crops such as cotton, finger millets, and sweetpotatoes. It has a markedly different cropping system from the other agroecological zones, and

Table 1. Odds ratios and probability for detection of two sweetpotato viruses in the same host plant ${ }^{\mathrm{a}}$

\begin{tabular}{|c|c|c|c|c|c|}
\hline \multirow[b]{2}{*}{ Virus 1} & \multirow[b]{2}{*}{ Virus 2} & \multirow[b]{2}{*}{ Odds ratio } & \multirow[b]{2}{*}{$P$ value $^{b}$} & \multicolumn{2}{|c|}{$95 \% \mathrm{CI}$ for odds ratio } \\
\hline & & & & Lower & Upper \\
\hline SPCSV & SPFMV & 2.90 & 0.000 & 2.04 & 4.09 \\
\hline SPCSV & SPMMV & 0.79 & 0.238 & 0.53 & 1.17 \\
\hline SPCSV & SPCFV & 0.55 & 0.111 & 0.27 & 1.15 \\
\hline SPFMV & SPMMV & 1.74 & 0.008 & 1.16 & 2.62 \\
\hline SPFMV & SPCFV & 2.22 & 0.066 & 0.95 & 5.20 \\
\hline SPMMV & SPCFV & 1.07 & 0.859 & 0.49 & 2.37 \\
\hline
\end{tabular}

${ }^{a}$ SPCSV = Sweet potato chlorotic stunt virus; SPFMV = Sweet potato feathery mottle virus; SPMMV = Sweet potato mild mottle virus; SPCFV = sweet potato chlorotic fleck virus.

$\mathrm{b}$ Level of significance that the two viruses occur together in the same host at a given odds ratio. 
sweetpotato is not continuously grown throughout the year. In contrast, in some parts of the tall grassland, mountain and particularly the tall grass-forest mosaic zones of central Uganda, piecemeal harvesting of sweetpotato is a common practice, and farmers may have many gardens planted in such a way that they get year-

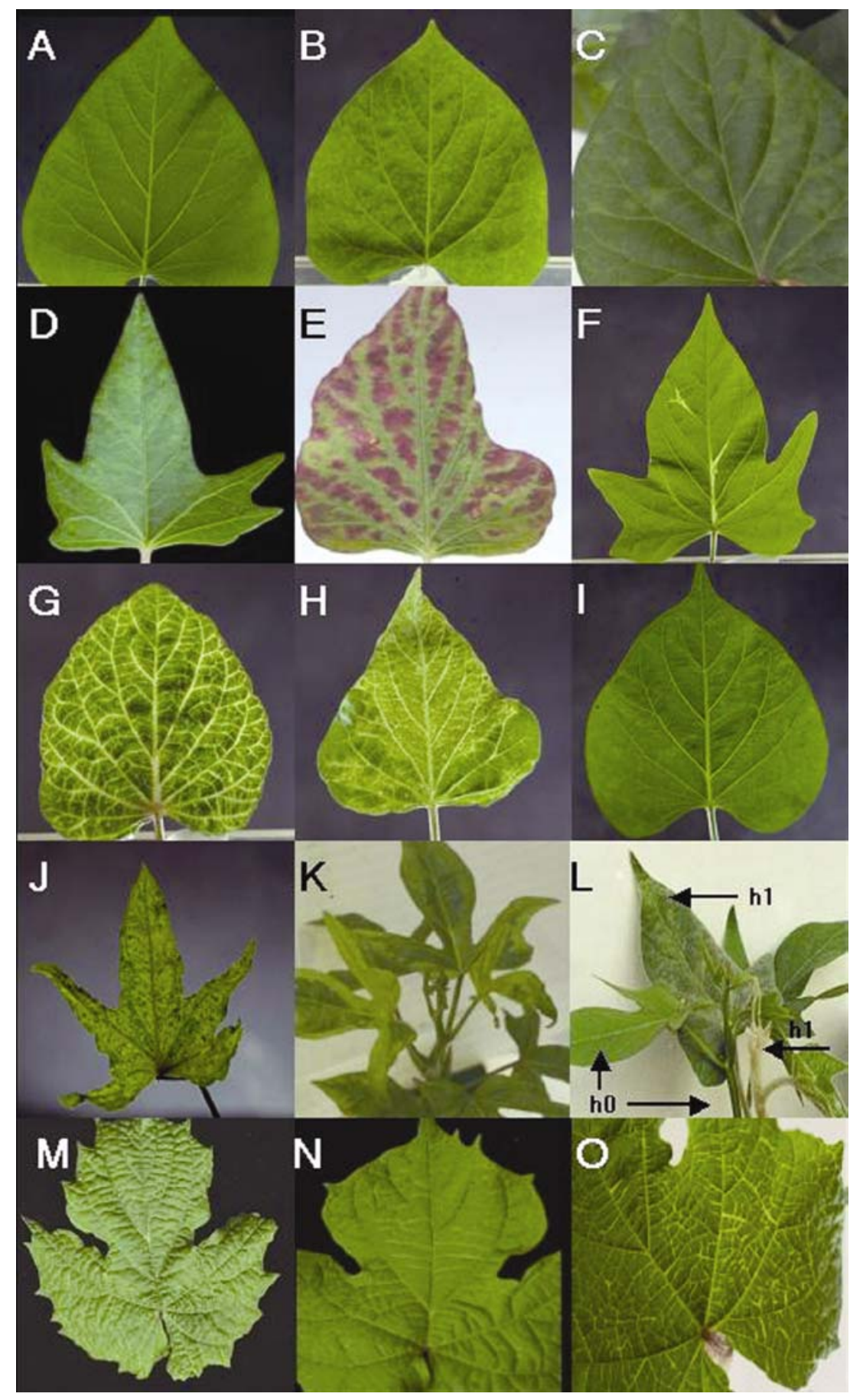

Fig. 5. Virus-associated symptoms observed in sweetpotato in Uganda. A, Leaf of healthy sweetpotato cv. Dimbuka. B, Mottling that intermittently developed on sweetpotato cv. Dimbuka that tested positive for only Sweet potato feathery mottle virus (SPFMV). C, Mottling in cv. Kyebandula-red characteristic of Sweet potato mild mottle virus (SPMMV). D, Diffuse chlorosis (pale) symptoms in cv. Tanzania infected with Sweet potato chlorotic stunt virus (SPCSV). E, Purpling in older leaves of cv. Tanzania infected with SPCSV. F, Vein chlorosis in cv. Sukaali infected with SPMMV and which had the hairy symptom in the field. G, Severe vein chlorosis in sweetpotato cv. Kyebandula-red infected with SPFMV and SPCSV. H, Chlorosis in sweetpotato cv. Dimbuka mixed infected by SPMMV and SPCSV. I, Symptoms associated with sweet potato chlorotic fleck virus (SPCFV) in cv. Lwakenya. $\mathbf{J}$ and $\mathbf{K}$, Leaf clearing (graying) in sweetpotato due to an unknown pathogen; the affected plants also show clearing of leaf margins $(\mathbf{K})$ and leaf distortion. $\mathbf{L}$, Two plants of the same clone with (h1) and without (h0) the hairiness disorder. M, Mild vein chlorosis and blistering of the leaf lamina in Ipomoea setosa when grafted onto sweetpotato plant with the leaf-clearing symptom of unknown etiology. N, Vein clearing in I. setosa grafted on sweetpotato cv. Dimbuka infected by SPFMV. $\mathbf{O}$, Vein chlorosis in I. setosa grafted on SPMMV-infected sweetpotato.

round harvest (5). Probably the low disease incidence in the short grassland savannah zone could partly be explained by the discontinuity in cultivation of sweetpotato. Disease incidence there followed a random pattern, suggesting a less dynamic mechanism for spread of sweetpotato viruses. Thus, phytosanitary practices such as planting healthy vines, early rouging of diseased vines, and discontinuous cropping can be good strategies in management of viral diseases in sweetpotato.

This study provides a quantitative assessment of the incidence and distribution of viruses and virus diseases in sweetpotato plants in Uganda, taking into account the major agroecological zones and cropping systems. The description of symptoms associated with sweetpotato viruses and viruslike agents may be a useful guide to diagnosis of sweetpotato diseases. The data will contribute to enhanced integrated disease management in sweetpotato crops.

\section{ACKNOWLEDGMENTS}

This study (project 771599/771502) is part of the East African Regional Network for Biotechnology, Biosafety and Biotechnology Policy Development program (BIO-EARN) funded by Sida/SAREC through the Stockholm Environment Institute (SEI). The authors acknowledge the International Potato Center (CIP), Lima, Peru, for providing the antibodies to sweetpotato viruses. Fruitful interaction with the project ICA4-CT2000-30007 funded by European Union is gratefully acknowledged.

\section{LITERATURE CITED}

1. Alicai, T., Fenby, N. S., Gibson, R. W., Adipala, E., Vetten, H. J., Foster, G. D., and Seal, S. E. 1999. Occurrence of two serotypes of sweet potato chlorotic stunt virus in East Africa and their associated differences in coat protein and HSP70 homologue gene sequences. Plant Pathol. 48:718-726.

2. Alvarez, V., Ducasse, D. A., Biderbost, E., and Nome, S. F. 1997. Sequencing and characterization of the coat protein and $3^{\prime}$ noncoding region of a new sweet potato potyvirus. Arch. Virol. 142:1635-1644.

3. Aritua, V., Adipala, E., Carey, E. E., and Gibson, R. W. 1998. Aspects of resistance to sweet potato virus disease in sweet potato. Ann. Appl. Biol. 132:387-398.

4. Aritua, V., Adipala, E., Carey, E. E., and Gibson, R. W. 1998. The incidence of sweet potato virus disease and virus resistance of sweet potato grown in Uganda. Ann. Appl. Biol. 132:399-411.

5. Bashaasha, B., Mwanga, R. O. M., Ocitti p'Obwoya, C., and Ewell, P. T. 1995. Sweet Potato in the Farming and Food systems of Uganda: A Farm Survey Report. International Potato Center (CIP) and National Agricultural Research Organization (NARO), Lima, Peru.

6. Bos, L. 1999. Plant Viruses - Unique and Intriguing Pathogens. Backhuys Publishers, Leiden, Netherlands.

7. CIP. 1999. CIP Sweet Potato Facts. A Compendium of Key Figures and Analysis for 33 Important Sweet Potato Producing Countries. International Potato Center, Lima, Peru.

8. Clark, C. A., and Moyer, J. M. 1988. Compendium of Sweet Potato Diseases. American Phytopathological Society, St Paul, MN.

9. Colinet, D., Kummert, J., and Lepoivre, P. 1996. Molecular evidence that the whiteflytransmitted sweet potato mild mottle virus belongs to distinct genus of the Potyviridae. 
Arch. Virol. 141:125-135.

10. Colinet, D., Kummert, P., and Lepoivre, P. 1997. Evidence of assignment of two strains of SPLV to the genus potyvirus based on coat protein and $3^{\prime}$ non-coding region sequence data. Virus Res. 49:91-100.

11. Di Feo L., Nome, S. F., Biderbost, E., Fuentes, S., and Salazar, L. F. 2000. Etiology of sweet potato chlorotic dwarf disease in $\mathrm{Ar}-$ gentina. Plant Dis. 84:35-39.

12. FAO. 1998. FAO Production Year Book for 1996. Food and Agriculture Organisation of the United Nations, Rome, Italy. pp. 91-92.

13. Fuentes, S., and Salazar, L. F. 1992. Identification of a new sweet potato virus. Fitopatologia 27:50.

14. Gibbs, A., and Mackenzie, A. 1997. A primer pair for amplifying part of the genome of all potyvirids by RT-PCR. J. Virol. Methods 63:9-16.

15. Gibbs, K. S., and Padovan, A. C. 1993. Detection of sweet potato feathery mottle in sweet potato grown in Northern Australia using an efficient and simple assay. Int. J. Pest Manag. 39:223-228.

16. Gibson, R. W., Mpembe, I., Alicai, T., Carey, E. E., Mwanga, R. O. M., Seal, S. E., and Vetten, H. J. 1998. Symptoms, aetiology and serological analysis of sweet potato virus disease in Uganda. Plant Pathol. 47:95-102.

17. Gibson, R. W., Mwanga, R. O. M., Kasule, S. Mpembe, I., and Carey, E. E. 1997. Apparent absence of viruses in most symptomless field grown potato in Uganda. Ann. Appl. Biol. 130:481-490.

18. Hansford, C. G. 1944. A probable virus disease of sweet potato. E. Afr. J. 10:126-127.

19. Hollings, M., Stone, O. M., and Bock, K. R. 1976. Purification and properties of sweet potato mild mottle, a whitefly borne virus from sweet potato (Ipomoea batatas) in East Africa. Ann. Appl. Biol. 82:511-528.

20. Hosmer, D. W., and Lemeshow, S., eds. 1989. Applied Logistic Regression. John Wiley \& Sons, Inc., New York.

21. Hughes, G., Madden, L. V., and Munkvold, G. P. 1996. Cluster sampling for disease incidence data. Phytopathology 86:132-137.
22. Karyeija, R. F., Gibson, R. W., Valkonen, J. P. T. 1998. The significance of sweet potato feathery mottle virus in subsistence sweet potato production in Africa. Plant Dis. 82:4-15.

23. Karyeija, R. F., Kreuze, J. F., Gibson, R. W., and Valkonen, J. P. T. 2000. Two serotypes of Sweetpotato feathery mottle virus in Uganda and their interaction with resistant sweetpotato cultivars. Phytopathology 90:1250-1255.

24. Karyeija, R. F., Kreuze, J. F., Gibson, R. W., and Valkonen, J. P. T. 2000. Synergistic interactions of a potyvirus and a phloem-limited crinivirus in sweet potato plants. Virology 269:26-36.

25. Kreuze, J. F., Karyeija, R. F., Gibson, R. W., and Valkonen, J. P. T. 2000. Comparisons of coat protein gene sequences show that East African isolates of Sweet potato feathery mottle virus form a genetically distinct group. Arch. Virol. 145:567-574.

26. Kreuze, J. F., Savenkov, E. I., and Valkonen, J. P. T. 2002. Complete genome sequence and analysis of the subgenomic RNAs of Sweet potato chlorotic stunt virus reveal several new features for the genus Crinivirus. J. Virol. 76:9260-9270.

27. Madden, L. V., and Hughes, G. 1999. Sampling for plant disease incidence. Phytopathology 89:1088-1103.

28. Matthews, R. E. F. 1991. The nature of dark green tissue. Pages 448-449 in: Plant Virology, 3rd ed. Academic Press, San Diego, CA.

29. Mettrick, H. 1993. Development Oriented Research in Agriculture: An ICRA Textbook. International Center for Development Oriented Research in Agriculture (ICRA), Wageningen, Netherlands.

30. Moyer, J. W., and Salazar, L. F. 1989. Virus and viruslike diseases of sweet potato. Plant Dis. 73:451-455.

31. Ngeve, J. M. 1990. Yield stability and yield depression in sweet potato cultivars susceptible to the sweet potato virus disease. J. Hortic. Sci. 65:225-230.

32. Nolasco, G., de Blas, C., Torres, V., and Ponz, F. 1993. A method combining immunocapture and PCR amplification in a microtiter plate for detection of plant viruses and subviral pathogens. J. Virol. Methods 45:201-218.

33. Nutter, F. W. 1997. Quantifying the temporal dynamics of plant virus epidemics: A review. Crop Prot. 16:603-618.

34. Palmer, K. E., Schnippenkoetter, W. H., and Rykicki, E. P. 1998. Geminivirus isolation and DNA extraction. Pages 41-52 in: Methods in Molecular Biology, vol. 81. G. D. Foster and S. C. Taylor, eds. Humana Press Inc., Totowa, NJ.

35. Schaefers, G. A., and Terry, E. R. 1976. Insect transmission of sweet potato disease agents in Nigeria. Phytopathology 66:642-645.

36. Sheffield, F. M. L. 1954. Erinose of sweet potato. Empire J. Exp. Agric. 22:97-100.

37. Sheffield, F. M. L. 1957. Virus diseases of sweet potato in East Africa. I. Identification of the viruses and their insect vectors. Phytopathology 47:582-590.

38. Valkonen, J. P. T., Rajamäki, M.-L., and Kekarainen, T. 2002. Mapping of viral genomic regions important in cross-protection between strains of a potyvirus. Mol. PlantMicrobe Interact. 15:683-692.

39. Van Regenmortel, M. H. V., Fauquet, C. M., Bishop, D. H. L., Carstens, E. B., Estes, M K., Lemon, S. M., Maniloff, J., Mayo, M. A. McGeoch, D. J., Pringle, C. R., and Wickner, R. B. 2000. Virus Taxonomy. Classification and Nomenclature of Viruses. 7th Report of the International Committee on Taxonomy of Viruses. Academic Press, San Diego, CA.

40. Verwoerd, T. C., Dekkar, M. M., and Hoekema, A. 1989. A small-scale procedure for rapid isolation of plant RNAs. Nucleic Acids Res. 17:2362.

41. Wisler, G. C., Duffus, J. E., Liu, H.-Y., and Li, R. H. 1998. Ecology and epidemiology of whitefly-transmitted closteroviruses. Plant Dis. 82:270-280.

42. Woolfe, J. A., ed. 1992. Sweet Potato, An Untapped Food Resource. Cambridge University Press, New York.

43. Wyatt, S. D., and Brown, J. K. 1996. Detection of subgroup III geminivirus isolates in leaf extracts by degenerate primers and polymerase chain reaction. Phytopathology $86: 1288-1293$ 